\title{
Pengembangan Modul Matematika Berbasis Problem solving pada Materi Vektor
}

\author{
Dewi Ariskasari 1, Dona Dinda Pratiwi 1 \\ 1Universitas Islam Negeri Raden Intan Lampung. Jalan Endro Suratmin, Sukarame, Bandar \\ Lampung 35133, Indonesia. \\ E-mail: dewisuharta27@gmail.com
}

\begin{abstract}
Abstrak
Penelitian ini di bertujuan untuk mengembangkan, mengetahui respon serta keefektifan modul matematika berbasis problem solving pada materi vektor. Jenis penelitian ini adalah penelitian dan pengembangan atau yang lebih dikenal dengan Research and Develompment (R\&D). Model pendekatan yang digunakan dalam penelitian ini yaitu ADDIE. Teknik analisis data pada penelitian ini digunakan untuk menghitung kevalidan dari para validator, respon pendidik dan peserta didik, dan keefektifan bahan ajar matematika. Hasil uji validasi yang dilakukan oleh validator adalah 3,24 kriteria cukup valid. Hasil respon pendidik 3,21 dengan kriteria menarik, respon uji coba skala kecil 3,4 dengan respon sangat menarik dan uji coba lapangan 3,8 dengan respon sangat menarik. Hasil uji efektifitas yang dilakukan saat uji lapangan mendapat persentase sebesar $61 \%$ dengan kriteria efektif. Dari data tersebut menunjukkan bahan ajar pembelajaran layak digunakan berdasarkan respon pendidik dan keefektifan yang dilakukan oleh peserta didik maka pengembangan modul matematika layak digunakan di sekolah.
\end{abstract}

Kata kunci: Bahan Ajar, Problem solving, Vektor

\begin{abstract}
This study aims to develop, determine the response and effectiveness of problem-based mathematical modules on vector material. This type of research is research and development or better known as Research and Development (R\&D). The approach model used in this study is ADDIE. Data analysis techniques in this study were used to calculate the validity of the validators, the response of educators and students, and the effectiveness of mathematics teaching materials. The results of the validation test conducted by the validator are 3.24 the criteria are quite valid. The results of educator responses 3.21 with interesting criteria, response to small-scale trials of 3.4 with very interesting responses and field trials of 3.8 with very interesting responses. The results of the effectiveness test conducted during the field test got a percentage of $61 \%$ with effective criteria. From these data it shows that instructional materials are feasible to use based on the educator's response and effectiveness carried out by students, so the development of mathematical modules is appropriate for use in schools.
\end{abstract}

Keywords: Teaching Materials, Problem solving, Vector.

\section{PENDAHULUAN}

Matematika merupakan salah satu bidang studi yang terus berkembang dari waktu ke waktu, sehingga menjadikan matematika lebih bersifat teoritis dan abstrak. Perkembangan matematika menjadikan pendidik harus bekerja ekstra dalam menstranfer ilmu kepada peserta didik. Inilah yang membuat peserta didik merasakan bahwa pelajaran matematika sulit dan membosankan sehingga peseta didik tidak mengetahui dan manfaat dalam kehidupan sehari-hari. Pemecahan masalah matematika pada kehidupan sehari-hari yang di lakukan oleh pendidik saat kegiatan belajar mengajar dapat menentukan apakah peserta didik dapat memahami konsep matematika yang telah dijelaskan(Pardimin \& Widodo, 2017). Salah satu materi yang sulit dipahami 
dalam pelajaran matematika yaitu materi vektor. Peserta didik mengalami kesulitan untuk menyelesaikan soal vektor dengan benar, sehingga mengakibatkan nilai peserta didik tidak memuaskan. Kesalahan dalam mengerjakan soal vektor matematika diakibatkan oleh peserta didik yang kurang paham pada materi vektor. Oleh karena itu diperlukan proses kegiatan belajar dengan menggunakan bahan ajar. Adapun bahan ajar yang dapat digunakan yaitu bahan ajar berupa modul.

Modul adalah bahan ajar yang disusun secara sistematis dan menarik yang mencakup isi materi, metode dan evaluasi yang dapat digunakan secara mandiri(Tjiptiany \& Muksar, 2016). Modul pembelajaran adalah program belajar mengajar yang di pelajari oleh peserta didik itu sendiri secara individu(Winkel, 2009). Penggunaan modul pembelaran dapat membuat peserta didik lebih tertarik dalam kegiatan belajar mengajar dan peserta didik juga mampu berpikir secara kreatif dan matematis(Anggoro, 2015). Pembelajaran menggunakan modul juga dapat memaksimalkan peserta didik untuk memecahkan masalah dengan kreatif dan matematis dalam kehidupan sehari-hari. Pembelajaran yang menggunakan model problem solving juga dapat membantu menumbuhkan kreatifitas peserta didik dalam menganalisis matematika. Dalam mengembangkan bahan ajar dapat dikombinasikan dengan model pembelajaran problem solving untuk mempermudah peserta didik dalam menyelesaikan masalah yang diberikan oleh pendidik.

Berdasarkan penelitian yang telah dilakukan sebelumnya, banyak peneliti yang sudah berusaha mengembangkan suatu bahan ajar berupa modul maupun bahan ajar lain dengan tujuan agar memudahkan dalam mencapai tujuan pembelajaran (Adi Pradana \& Triyanto, 2013; Anggoro, 2015; Fitri, Septia, \& Yunita, 2013; Kurniati, 2016; Mufidah,
2014; NO, 2016; Rahma, Mulyani, \& Masyikuri, 2017; Sandiyanti \& Rakhmawati, 2018; Sari, Farida, \& Syazali, 2016; Supriadi, Farida, \& Lestari, 2018; Taufik Aditia \& Muspiroh, 2013; Tri Hastuti, Sunarno, \& Sukarmin, 2014; Utami, Jatmiko, \& Suherman, 2018; Wati, 2015; Wibowo \& Pratiwi, 2018) serta beberapa penelitian yang menggunakan pendekatan Problem solving (Anggoro, 2015; Krawec, 2014; Mustofa, Susilo, \& Muhdhar, 2016; Nopitasari, n.d.; Wijayanti \& Sungkono, 2017; Yuliati, Riantoni, \& Mufti, 2018). Tetapi penelitian mengenai pengembangan bahan ajar berupa modul matematika berbasis Problem solving belum pernah dilakukan sebelumnya.

Berdasarkan penelitian terdahulu, keterbaruan penelitian ini adalah mengembangkan bahan ajar berupa modul matematika berbasis Problem solving pada materi vektor. Maka penelitian ini bertujuan untuk mengembangkan, mengetahui responden, dan keefektifan modul matematika berbasis problem solving pada materi vector

\section{METODE}

Jenis penelitian yang digunakan adalah penelitian dan pengembangan (RnD) yang digunakan untuk menghasilkan produk dan menguji keefektifan produk tersebut(Atika \& Mz, 2016). Metode penelitian mengacu pada model yang dikembangkan oleh Dick and Carry yaitu, ADDIE model ini meliputi, 1) Analysis, 2)Design, 3)Development, 4)Implimentation, dan 5)Evaluation (Tegeh \& dkk, 2014). Instrumen Yang di lakukan pada penelitian ini menggunakan instrument test dan non test. Secara umum, model penelitian ini dapat dilihat pada Gambar 1.(Budiarta, Margi, \& Sudarma, 2014)

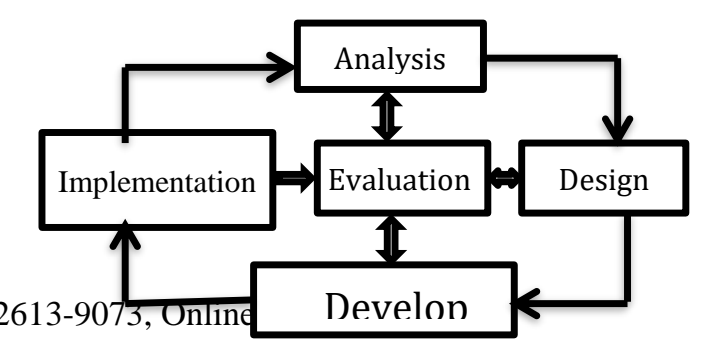


Desimal, 2 (3), 2019 - 251

Dewi Ariskasari, Dona Dinda Pratiwi

Gambar 1. Langkah-langkah penggunaan ADDIE

Teknik pengumpulan data yang digunakan untuk mengavaluasi dan memvalidasi terhadap modul yang akan dikembangkan adalah angket dan tes. Analisis hasil uji validitas modul yang dikembangkan dapat dilakukan dengan beberapa langkah, yaitu memberikan skor jawaban dengan kriteria sangat baik (skor 4), baik (skor 3), cukup (skor 2), dan kurang (skor 1); memberikan nilai presentase dengan rumus (Putra \& Anggraini, 2016):

$$
\bar{X}=\frac{\sum_{i=1}^{n} x_{i}}{n}
$$

Ket : $\bar{X}=$ nilai rata-rata akhir

: $x_{i}=$ nilai kridealan angkrt tiap aspe

: $\mathrm{n}$ = Banyaknya pernataan

Hasil penilaian masing masing validator dicari rata-ratanya dan di konversikan kedalam pertanyaan untuk menentukan kevalidan dan kelayakan modul matematika berbasis problem solving pada materi vektor. Konversian skor menjadi pertanyaan penilaian ini dapat dilihat dalam Tabel 1(Pratama, 2016).

Tabel 1. Kriteria Validasi (Modifikasi)

\begin{tabular}{|c|c|c|}
\hline Skor Kualitas & $\begin{array}{c}\text { Kriteria } \\
\text { Kelavakan }\end{array}$ & Keterangan \\
\hline $3,26<\bar{X} \leq 4,00$ & Valid & Tidak Revisi \\
\hline $2,51<\bar{X} \leq 3,26$ & Cukup Valid & $\begin{array}{c}\text { Revisi } \\
\text { Sebagian }\end{array}$ \\
\hline $1,76<\bar{X} \leq 2,51$ & $\begin{array}{c}\text { Kurang } \\
\text { Valid }\end{array}$ & $\begin{array}{c}\text { Revisi } \\
\text { Sebagian dan } \\
\text { Pengkajian }\end{array}$ \\
\hline $1,00<\bar{X} \leq 1,76$ & Tidak Valid & $\begin{array}{c}\text { Ulang } \\
\text { Tidak } \\
\text { Digunakan }\end{array}$ \\
\hline
\end{tabular}

Analisis data dari respon peserta didik dan pendidik terhadap penggunaan modul memiliki 4 pilihan jawaban sesuai dengan konten pertanyaan. Masingmasing pilihan jawaban memiliki skor yang berbeda yang mengartikan tingkat kesesuaian produk bagi pengguna. Skor penilaian dari tiap jawaban dapat dilihat dalam Tabel 2(Priliyanti, 2012).

Tabel 2. Pedoman Penskoran Angket Respon

\begin{tabular}{lcc}
\hline \multicolumn{1}{c}{ Kategori } & \multicolumn{2}{c}{ Skor } \\
& $\begin{array}{c}\text { Pertanyaan } \\
\text { Positif }\end{array}$ & $\begin{array}{c}\text { Pertanyaan } \\
\text { Negatif }\end{array}$ \\
Sangat Setuju & 4 & 1 \\
(SS) & 3 & 2 \\
Setuju (S) & 2 & 3 \\
Tidak Setuju & (TS) & 4 \\
Sangat Tidak & 1 & 4 \\
Setuju (STS) & 1 & \\
\hline
\end{tabular}

Hasil dari skor penilaian masingmasing peserta didik ataupun pendidik kemudian dicari rata-rata dan di konversikan ke pertanyaan untuk melihat kriteria respon, Konversian skor menjadi pertanyaan penilaian ini dapat dilihat pada Tabel 3(Putra \& Anggraini, 2016).

Tabel 3. Kriteria Respon

\begin{tabular}{cc}
\hline Skor Kualitas & Kriteria \\
$3,26<\bar{X} \leq 4,00$ & Sangat Menarik \\
$2,51<\bar{X} \leq 3,26$ & Menarik \\
$1,76<\bar{X} \leq 2,51$ & Cukup Menarik \\
$1,00<\bar{X} \leq 1,76$ & Tidak Menarik \\
\hline
\end{tabular}

Teknik analisis keefektifan modul menggunakan tes hasil belajar dengan 5 soal yang terdapat di modul dengan bobot soal yang sama. Skoring yang digunakan menggunakan bentuk skala 1-20. Dengan demikian pendidik tidak memberi angka nol terhadap jawaban yang salah. Rumus menghitung persentase ketuntasan peserta didik digunakan rumus ;

$$
\begin{aligned}
P= & \frac{p_{a}}{p_{b}} \times 100 \% \\
\text { Ket : } \mathrm{P}= & \text { Persentase } \\
& \text { Ketuntasan Peserta } \\
& \text { Didik } \\
: p_{a}= & \text { Jumlah Peserta Didik } \\
: p_{b}= & \text { yang Tuntas } \\
& \text { Jumlah Peserta Didik Seluruh }
\end{aligned}
$$


Hasil penilaian seluruh peserta didik kemudian di cari rata-ratanya. Dikonversikan ke dalam pertanyaan penilaian ini dapat dilihat pada Tabel 4(Yuliana, 2017).

Tabel 4. Kriteria Penilaian Keefektifan

\begin{tabular}{cc}
\hline Persentase Ketuntasan & Kriteria \\
$P>80$ & Sangat Efektif \\
$60<P \leq 80$ & Efektif \\
$40<P \leq 60$ & Cukup Efektif \\
$20<P \leq 40$ & Kurang Efektif \\
$P \leq 20$ & Tidak Efektif \\
\hline
\end{tabular}

\section{HASIL DAN PEMBAHASAN}

1. Tahap analisis yang dilakukan saat pra penelitian di ketahui bahwa saat proses pembelajaran peserta didik kurang memahami konsep vektor sehingga mengakibatkan nilai ujian peserta didik mendapat nilai yang tidak maksimal. Sehingga peneliti memilih mengembangkan bahan ajar pembelajaran yang dikombinasi dengan model pembelajaran problem solving.

2. Tahap design (perancangan) dilakukan penyusunan kerangka dan ide dalam pembuatan modul pembelajaran. Penyusunan desain agar peneliti memiliki gambaran tentang tampilan dan isi pada modul yang akan di buat. Perancangan instrumen dilakukan untuk menyusun gambaran angket validasi media yang telah dibuat. Instrumen tersebut diantaranya adalah angket ahli materi dan angket ahli media serta respon pendidik dan respon peserta didik.

3. Tahap Development merupakan tahap pembuatan modul pembelajaran. Produk selesai dibuat, kemudian di lakukan evaluasi oleh para ahli yang disebut dengan validasi. Tujuan validasi digunakan untuk mengetahui kekurangan dan kelemahan media serta memperoleh masukan masukan guna memperbaiki modul yang akan dikembangkan. Validasi juga ditunjukkan untuk memperoleh penilaian apakah modul sudah layak atau belum di uji cobakan. Hasil Validasi para ahli materi dan media di lihal pada Tabel 5.

Tabel 5 Hasil Validasi Oleh ahli materi tahap 1

\begin{tabular}{|c|c|c|c|}
\hline No & Aspek & $\begin{array}{c}\text { Nilai } \\
\text { Validasi }\end{array}$ & Kriteria \\
\hline 1 & Kelayakan Isi & 2,75 & $\begin{array}{c}\text { Cukup } \\
\text { Valid }\end{array}$ \\
\hline 2 & $\begin{array}{l}\text { Ketetapan } \\
\text { Kecakupan }\end{array}$ & 2,67 & $\begin{array}{l}\text { Cukup } \\
\text { Valid }\end{array}$ \\
\hline 3 & $\begin{array}{l}\text { Problem } \\
\text { solving }\end{array}$ & 2,94 & $\begin{array}{l}\text { Cukup } \\
\text { Valid }\end{array}$ \\
\hline 4 & Bahasa & 2,33 & $\begin{array}{c}\text { Kurang } \\
\text { Valid }\end{array}$ \\
\hline & Rata-rata & 2.67 & $\begin{array}{l}\text { Cukup } \\
\text { Valid }\end{array}$ \\
\hline
\end{tabular}

Berdasarkan Tabel 5 bahwa pada aspek kelayakan isi mendapat nilai rata rata 2,75 dengan kriteria cukup valid, pada aspek ketetapan isi mendapat nilai rata-rata 2,67 dengan kriteria cukup valid, pada aspek problem solving mendapat nilai rata-rata 2,94 dengan kriteria cukup valid dan pada aspek bahasa mendapat kriteria kurang valid. Skor seluruh aspek mendapat skor 2,67 dengan kriteria cukup valid. Ada aspek yang mendapat nilai tidak valid. Sehingga, materi yang ada pada modul yang akan di kembangkan harus direvisi terlebih dahulu, setelah direvisi mendapat nilai dari validator ahli materi dapat dilihat pada Tabel 6 .

Tabel 6. Hasil Validasi Oleh Ahli Materi Tahap 2

\begin{tabular}{|c|c|c|c|}
\hline No & Aspek & $\begin{array}{c}\text { Nilai } \\
\text { Validasi }\end{array}$ & Kriteria \\
\hline 1 & Kelayakan Isi & 3,25 & $\begin{array}{l}\text { Cukup } \\
\text { Valid }\end{array}$ \\
\hline 2 & $\begin{array}{l}\text { Ketetapan } \\
\text { Kecakupan }\end{array}$ & 3 & $\begin{array}{l}\text { Cukup } \\
\text { Valid }\end{array}$ \\
\hline
\end{tabular}


Desimal, 2 (3), 2019 - 253

Dewi Ariskasari, Dona Dinda Pratiwi

\begin{tabular}{clcc}
\hline 3 & Problem & 3,22 & Cukup \\
& Solving & & Valid \\
4 & Bahasa & 3,33 & Valid \\
& Rata-rata & 3,2 & Cukup \\
& & & Valid \\
\hline
\end{tabular}

Berdasarkan Tabel 6 pada aspek

Kelayakan isi mendapat skor 3,25 dengan kriteria cukup valid, pada aspek ketetapan kecakupan mendapat skor 3 dengan kriteria cukup valid, pada aspek problem solving mendapat skor 3,22 denagn kriteria valid dan pada aspek bahasa mendapat skor 3,33 dengan kriteria valid. Skor rata-rata penilaian seluruh aspek sebesar 3,2 dengan kriteria cukup valid keeran berada pada rentang $2,51<\bar{X} \leq$ 3,26 , sehingga modul matematika layak digunakan dengan revisi sebagian. Saran perbaikan dari para ahli materi dijadikan bahan perbaikan dalam penyempurnaan pembuatan modul pembelajran. Beberapa saran yang di berikan oleh ahli materi antara lain; penggunaan bahasa yang jelas dan informasi yang disampaiharus lebih spesifik lagi. Berikut hasil validasi oleh ahli media pembelajaran, lihat pada Tabel 7.

Tabel 7. Hasil Validasi Oleh Ahli Media

\begin{tabular}{|c|c|c|c|}
\hline No & Aspek & $\begin{array}{c}\text { Nilai } \\
\text { Validasi }\end{array}$ & Kriteria \\
\hline 1 & $\begin{array}{l}\text { Ukuran } \\
\text { Modul }\end{array}$ & 3,33 & Valid \\
\hline 2 & $\begin{array}{l}\text { Desain } \\
\text { Kulit } \\
\text { Modul }\end{array}$ & 2,61 & $\begin{array}{c}\text { Cukup } \\
\text { Valid }\end{array}$ \\
\hline 3 & $\begin{array}{l}\text { Desain Isi } \\
\text { Modul } \\
\text { Rata-rata }\end{array}$ & $\begin{array}{c}3 \\
2,98\end{array}$ & $\begin{array}{c}\text { Cukup } \\
\text { Valid } \\
\text { Cukup } \\
\text { Valid } \\
\end{array}$ \\
\hline
\end{tabular}

Berdasarkan $\quad$ Tabel 7 ahli media memberikan nilai pada aspek ukuran modul mendapat skor 3,33 dengan kriteria valid, pada aspek Desain kulit modul mendapat skor 2,61 dengan kriteria cukup valid dan pada aspek desain isi modul mendapat skor 3 dengan kriteria cukup valid. Rata-rata skor seluruh aspek mendapat skor 2,98 dengan kriteria cukup menarik. Ada beberapa saran yang diberikan oleh validator ahli media sehingga media yang direvisi kemuadian di validasi lagi oleh ahli validasi media dapat dilihat pada Tabel 8.

Tabel 8. Hasil Validasi Oleh Ahli Media Tahap 2

\begin{tabular}{|c|c|c|c|}
\hline No & Aspek & $\begin{array}{c}\text { Nilai } \\
\text { Validasi }\end{array}$ & Kriteria \\
\hline 1 & $\begin{array}{l}\text { Ukuran } \\
\text { Modul }\end{array}$ & 3,5 & Valid \\
\hline 2 & $\begin{array}{l}\text { Desain } \\
\text { Kulit } \\
\text { Modul }\end{array}$ & 3,17 & $\begin{array}{l}\text { Cukup } \\
\text { Valid }\end{array}$ \\
\hline 3 & $\begin{array}{l}\text { Desain Isi } \\
\text { Modul } \\
\text { Rata-rata }\end{array}$ & $\begin{array}{l}3,22 \\
3,29\end{array}$ & $\begin{array}{l}\text { Cukup } \\
\text { Valid } \\
\text { Valid }\end{array}$ \\
\hline
\end{tabular}

Berdasarkan Tabel 8, skor rata-rata penialain modul oleh ahli media pembelajaran 3,29 dengan kriteria valid karena berad apada rentang $3,26<\bar{X} \leq 4,00$. Saran perbaikan yang diberikan oleh ahli media pembelajaran antara lain adalah memperbaiki kulit modul (cover), garis tepi lebih di perjelas dan ilustrasi gambar lebih di perjelas. Saran yang diberikan untuk menyempurnakan modul yang dikembangkan. Berikut hasil penilaian secara keseluruhan, dilihat pada Tabel 9.

Tabel 9. Hasil Validasi Secara Keseluruhan

\begin{tabular}{clcc}
\hline No & \multicolumn{1}{c}{ Ahli } & Validasi & Validasi \\
& Validasi & Tahap 1 & Tahap 2 \\
1 & $\begin{array}{l}\text { Ahli } \\
\text { Materi }\end{array}$ & 2,67 & 3,2 \\
2 & $\begin{array}{l}\text { Ahli } \\
\text { Media } \\
\text { Rata-rata }\end{array}$ & 2,98 & 3,29 \\
& 2,82 & 3,24 \\
\hline
\end{tabular}

Berdasarkan Tabel 9, Skor Ratarata Penilaian modul oleh ahli materi dan ahli media mendapat penilaian sebesar 3,24 dengan kriteria cukup valid karena berada pada rentang $2,51<\bar{X} \leq 3,26$. Dapat di lihat perbandingan menggunakan grafik dibawah ini dengan Gambar 2. 
Desimal, 2 (3), 2019 - 254

Dewi Ariskasari, Dona Dinda Pratiwi

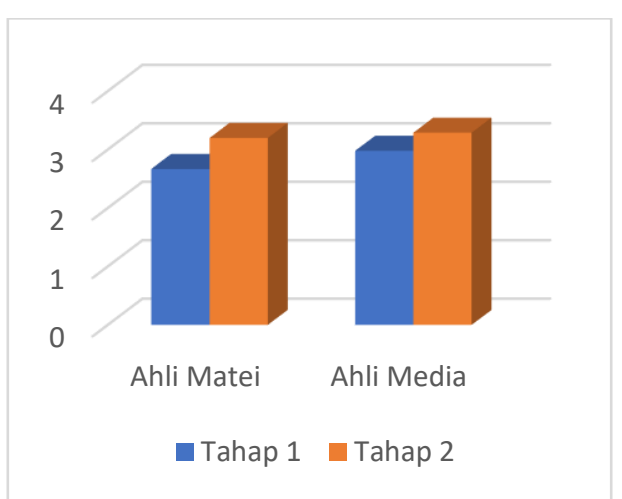

Gambar 2. Perbandingan validasi tahap 1 dan tahap 2

Berdasarkan Gambar 2 pada garafik diatas terlihat jelas bahwa perbandingan tahap 2 lebih tinggi disbanding dengan tahap 2. Oleh karena itu dapat disimpulkan bahwa menurut ahli materi dan ahli media modul yang dikembangkan telah valid. Setelah modul matematika telah di validasi oleh para ahli. modul matematika siap untuk di uji cobakan.

4. Tahap Implimentation, merupakan tahap uji coba skala kecil, ujicoba lapangan dan respon pendidik terhadap modul yang di kembangkan. Hail respon pendidik yang akan disajikan pada Tabel 10 .

\begin{tabular}{|c|c|c|c|}
\hline No & Aspek & $\begin{array}{c}\text { Nilai } \\
\text { Respon }\end{array}$ & Kriteria \\
\hline 1 & Kualitas Isi & 3,25 & Menarik \\
\hline 2 & $\begin{array}{l}\text { Ketetapan } \\
\text { Kecakupan }\end{array}$ & 3,11 & Menarik \\
\hline 3 & $\begin{array}{l}\text { Problem } \\
\text { solving }\end{array}$ & 3,27 & $\begin{array}{c}\text { Sangat } \\
\text { Menarik }\end{array}$ \\
\hline 4 & Tampilan & 3,16 & Menarik \\
\hline 5 & $\begin{array}{l}\text { Bahasa } \\
\text { Rata-rata }\end{array}$ & $\begin{array}{l}3,13 \\
3,18\end{array}$ & $\begin{array}{l}\text { Menarik } \\
\text { Menarik }\end{array}$ \\
\hline
\end{tabular}

Berdasarkan Tabel 10, skor penilaian respon pendidik 3,18, dengan kriteria menarik karena berada pada rentang $2,51<\bar{X} \leq 3,26$. beberapa saran perbaikan yang dijadikan bahan penyempurnaan modul pembelajaran. Berikut hasil ujicoba skala kecil dapat dilihat pada tabel 11.

Tabel 11. Respon Peserta didik Skala Kecil

\begin{tabular}{|c|c|c|c|}
\hline No & Aspek & $\begin{array}{l}\text { Nilai } \\
\text { Respon }\end{array}$ & Kriteria \\
\hline 1 & $\begin{array}{l}\text { Kualitas } \\
\text { Isi }\end{array}$ & 3,33 & $\begin{array}{c}\text { Sangat } \\
\text { Menarik }\end{array}$ \\
\hline 2 & Tampilan & 3,41 & $\begin{array}{c}\text { Sangat } \\
\text { Menarik }\end{array}$ \\
\hline \multirow[t]{2}{*}{3} & Bahasa & 3,58 & $\begin{array}{c}\text { Sangat } \\
\text { Menarik }\end{array}$ \\
\hline & Rata-rata & 3,44 & $\begin{array}{c}\text { Sangat } \\
\text { menarik }\end{array}$ \\
\hline
\end{tabular}

Berdasarkan Tabel 11, skor rata-rata respon pendidik skala kecil 3,44 dengan kriteria sangan menarik. Terdapat beberapa saran perbaikan yang dijadikan bahan pertimbangan dalam penyempurnaan modul. Saran yang diberikan antara lain gambar yang digunakan kurang jelas. Berdasarkan yang direvisisi. Berdasarkan saran-saran yang diterima selanjutnya diuji coba lapangan. Berikut hasil uji coba lapangan terlihat pada Tabel 12 .

Tabel 12 Uji Coba Lapangan

\begin{tabular}{|c|c|c|c|}
\hline No & Aspek & $\begin{array}{c}\text { Nilai } \\
\text { Respon }\end{array}$ & Kriteria \\
\hline 1 & $\begin{array}{l}\text { Kualitas } \\
\text { Isi }\end{array}$ & 3,82 & $\begin{array}{c}\text { Sangat } \\
\text { Menarik }\end{array}$ \\
\hline 2 & Tampilan & 3,86 & $\begin{array}{c}\text { Sangat } \\
\text { Menarik }\end{array}$ \\
\hline \multirow[t]{2}{*}{3} & Bahasa & 3,75 & $\begin{array}{c}\text { Sangat } \\
\text { Menarik }\end{array}$ \\
\hline & Rata-rata & 3,81 & $\begin{array}{c}\text { Sangat } \\
\text { menarik }\end{array}$ \\
\hline
\end{tabular}

Berdasarkan Tabel 12 didapat hasil responden uji coba lapangan adalah 3,81 denagn kriteria sangat menarik karena berad pada rentan $3,26<\bar{X} \leq$ 4,00. Pada saat pertemuan siswa diberikan pretest dan postest untuk menunjukkan efektifitas dengan menggunakan modul pembelajaran yang telah dikembangkan. Tingkat efektifitas dapat diketahui dengan membandingkan hasil pretest dan post test yang di peroleh oleh peserta didik dengan nilai KKM . Nilai KKM untuk kelas $X$ adalah 66 . Nilai $\geq 66$ termasuk kategori tuntas dan nilai $<$ 66 termasuk kategori tidak tuntas. Berikut hasil pretest yang dilakukan oleh peserta didik sebelum 
Desimal, 2 (3), 2019 - 255

Dewi Ariskasari, Dona Dinda Pratiwi

menggunakan modul yang akan di kembangkan, lihat pada Tabel 13.

Tabel 13 Hasil Pertest Peserta Didik

\begin{tabular}{clcc}
\hline No & $\begin{array}{c}\text { Jumlah } \\
\text { Siwa }\end{array}$ & Interval & Kriteria \\
1 & 4 & $\geq 66$ & Tuntas \\
2 & 14 & $<66$ & Tidak Tuntas \\
& Rata-rata & $22 \%$ & Tidak Efektif \\
\hline
\end{tabular}

Berdasarkan Tabel 13 terlihat bahwa 4 peserta didik yang tuntas dalam melakukan uji pretest dan 14 peserta didik yang tidak tuntas dalam mengerjakan uji pretest. Selesai di kakukan uji pretest peneliti mengenalkan modul yang akan dikembangkan kepada peserta didik dan menjelaskan aturan menyelesaikan pemecahan masalah, kemudian dilakukan lah uji post test untuk melihat kefektifan bahan ajar yang akan dikembangkan, dapat dilihat pada Tabel 14.

Tabel 14 Hasil Post Test Peserta Didik

\begin{tabular}{clcc}
\hline No & Jumlah Siwa & Interval & Kriteria \\
1 & 11 & $\geq 66$ & Tuntas \\
2 & 7 & $<66$ & Tidak \\
& Rata-rata & $61 \%$ & Tuntas \\
& & & Efektif \\
\hline
\end{tabular}

Berdasarkan tabel 14 terlihat bahwa 11 peserta didik yang tuntas saat mengerjakan uji post test dan 7 peserta didik yang tidak tuntas mengerjakan uji post test. Terlihat bahwa perbedaan hasil uji pretest dan uji post testpada Gambar 3.

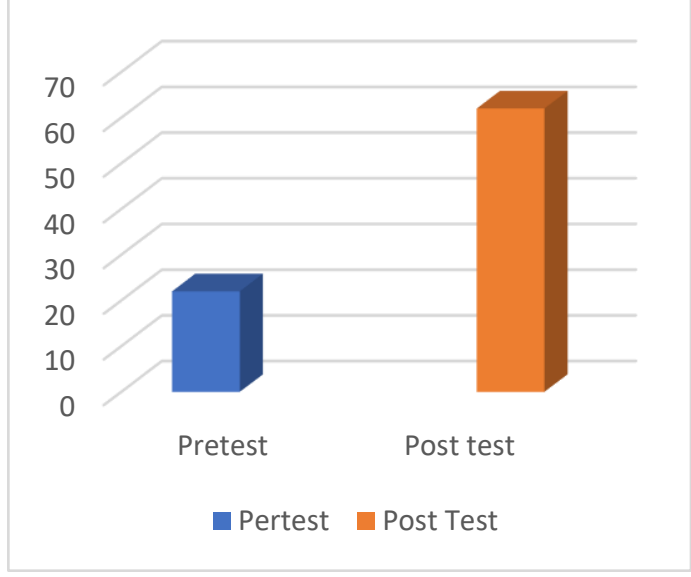

Gambar 3 Perbedaan Pretest dan Post test.

Pada Gambar 3 terlihat bahwa pada saat uji pretest dan uji post test mengalami peningkatan hingga mendapat persentase efektif. Sehingga bahan ajar matematika yang akan di kembangkan layak untuk di gunakan dalam proses pembelajaran di dalam kelas.

5. Tahap terakhir adalah tahap Evaluation. Pada tahap ini dilakukan evaluasi dari tahap analisis hingga tahap implementasi. Perbaikan dilakukan berdasarkan hasil penelitian dari validator, respon pendidik dan respon peserta didik. Semua saran dan perbaikan yang dilakukan terhadap bahan ajar yang dikembangkan direvisi dengan baik.

Model Problem solving berpengaruh positif terhadap hasil belajar peserta didik dan mampu membantu peserta didik lebih aktif berpikir selama pembelajaran terutama dalam pembuktian suatu konsep berdasarkan pengamatan dan analisis yang mereka lakukan(Widiana, Jampel, \& Jampel, 2016). Penelitian yang sebelumnya yang menggunakan model pembelajaran problem solving pada materi vektor adalah pengembangan perangkat pembelajaran berbasis problem solving pada materi vektor meliputi :Pengembangan perangkat pembelajaran vektor dengan pendekatan Creative problem solving kelas XI SMA Teknokestan(Atsnan, 2015).

\section{SIMPULAN DAN SARAN}

Berdasarkan hasil penelitian dapat disimpulkan bahwa modul matamatika yang di kembangkan mendapat respon yang baik dari pendidik dan peserta didik. Pada keefektifan modul yang di kembangkan juga mendapat presentase 
yang efektif. Maka dari beberapa tujuan diatas dapat disimpulkan bahwa pengembangan modul pembelajaran matematika berbasisi problem solving pada ,ateri vektor layak di gunakan pada proses pembelajaran.

Saran yang dapat diberikan pada penelitian selanjutnya yaitu hendaknya bahan ajar modul yang berbasiskan problem solving dapat dikembangkan dengan materi yang berbeda atau mengembangkan bahan ajar dengan pendekatan lain dalam pembelajaran matematika.

\section{DAFTAR PUSTAKA}

Adi Pradana, R., \& Triyanto. (2013). Efektivitas Pengembangan Modul Pebelajaran CNC I Pada Program Studi D3 Teknik Mesin Universitas Negeri Surabaya. JTM, 1(2), 48-57.

Anggoro, B. S. (2015). Pengembangan Modul Matematika Dengan Strategi Problem Solving untuk Mengukur Tingkat Kemampuan Berpikir Kreatif Matematis Siswa. Al-Jabar: Jurnal Pendidikan Matematika, 6(2), 121129.

Atika, N., \& Mz, Z. A. (2016). Pengembangan LKS Berbasis Pendekatan Rme Untuk Menumbuhkembangkan Kemampuan Berpikir Kritis Matematis, 2(2), 103-110.

Atsnan, M. F. (2015). Pengembangan Perangkat Pembelajaran Vektor dengan Pendekatan Creative Problem Solving Kelas XI SMK Teknokestan. Riset Pendidikan Matematika. https://doi.org/10.21831/jrpm.v2i1. 7148

Budiarta, I. W., Margi, I. K., \& Sudarma, I. K. (2014). Pengembangan Multimedia Interaktif Model ADDIE Untuk Meningkatkan Motivasi Belajar Sejarah Siswa Kelas X-1 Semester Genap di SMAN 1 Sukasada, Buleleng, Bali. Jurnal Widya Winayata. https://doi.org/10.1111/j.1365-
246X.1961.tb06803.x

Fitri, D. Y., Septia, T., \& Yunita, A. (2013).

Pengembangan Modul Kalkulus 2 Pada Program Studi Pendidikan Matematika di STKIP PGRI Sumatera Barat. Jurnal Pelangi, 6(1), 65-76.

Krawec, J. L. (2014). Problem Representation and Mathematical Problem Solving of Students of Varying Math Ability. Journal of Learning Disabilities, 47(2), 103-115. Kurniati, A. (2016). Pengembangan Modul Matematika Berbasis Kontekstual Terintegrasi Ilmu Keislaman. AlKhwarizmi: Jurnal Pendidikan Matematika Dan Ilmu Pengetahuan Alam, 4(1), 43-58.

Mufidah, C. I. (2014). Pengembangan Modul Pembelajaran pada Kompetensi Dasar Hubungan Masyarakat Kelas X APK 2 di SMK N 10 Surabaya. Jurnal Administrasi Perkantoran (JPAP), 2(2), 1-17.

Mustofa, Z., Susilo, H., \& Muhdhar, M. H. I. Al. (2016). Penerapan Model Pembelajaran Problem Based Learning Melalui Pendekatan Kontekstual Berbasis Lesson Study Untuk Meningkatkan Kemampuan Memecahkan Masalah Dan Hasil Belajar Kognitif Siswa SMA. Jurnal Pendidikan: Teori, Penelitian, Dan Pengembangan, 1(5), 885-889.

NO, I. N. (2016). Pengembangan Modul Berbasis Penemuan Terbimbing (Guided Discovery) Pada Materi Mempersiapkan Pertemuan/Rapat Pada Kelas XI APK di SMK Ketintang Surabaya. Jurnal Administrasi Perkantoran (JPAP), 4(3), 1-6.

Nopitasari, D. (n.d.). Pengaruh Model Pembelajaran Creative Problem Solving (Cps) Terhadap Kemampuan Penalaran Adaptif Matematis Siswa. Ma T H L I N E: Jurnal Matematika Dan Pendidikan Matematika.

Pardimin, \& Widodo, S. A. (2017). Development Comic Based Problem Solving in Geometry. Iejme - 
Desimal, 2 (3), 2019 - 257

Dewi Ariskasari, Dona Dinda Pratiwi

Mathematics Education, 12(3), 233241.

https://doi.org/10.1007/s11575-

011-0093-0

Pratama, D. (2016). Pengembangan Modul Matematika Untuk Pembelajaran Berbasis Masalah (Problem Based Learning) pada materi himpunan kelas VII SMP.

Priliyanti, P. (2012). Pengembangan Media Pembelajaran Matematika Berbasis Multimedia Interaktif Pada Materi Turunan Fungsi. Jurnal Ilmiah AdMathEdu, (Vol 2, No 2 (2012): Desember), 1-9.

Putra, R. W. Y., \& Anggraini, R. (2016). Pengembangan Bahan Ajar Materi Trigonometri Berbantuan Software iMindMap Pada Siswa SMA. Al-Jabar: Jurnal Pendidikan Matematika, 7(1), 39-47.

Rahma, S. Z., Mulyani, S., \& Masyikuri, M. (2017). Pengembangan Modul Berbasis SETS (Science, Environment, Technology, Society) Terintegrasi Nilai Islam di SMAI Surabaya pada Materi Ikatan Kimia. Jurnal Pendidikan, 2(1).

Sandiyanti, A., \& Rakhmawati, R. (2018). Pengembangan Modul Bilingual Bergambar Berbasis Quantum Learning pada Materi Peluang. Desimal: Jurnal Matematika, 1(2), 157-164.

Sari, F. K., Farida, \& Syazali, M. (2016). Pengembangan Media Pembelajaran (Modul) berbantuan Geogebra Pokok Bahasan Turunan. Al-Jabar: Jurnal Pendidikan Matematika, 7(2), 135151.

Supriadi, N., Farida, \& Lestari, B. D. (2018). Pengembangan Modul Kalkulus Pada Materi Turunan Bernuansa Keislaman dengan Pendekatan Penemuan Terbimbing. In YSSTEE International Conference (pp. 1-11).

Taufik Aditia, M., \& Muspiroh, N. (2013). Pengembangan Modul Pembelajaran Berbasis Sains, Lingkungan,
Teknologi, Masyarakat dan Islam ( Salingtemasis) Dalam Meningkatkan Hasil Belajar Siswa Pada Konsep Ekosistem Kelas X di SMA NU Lemahabang Kabupaten Cirebon. Jurnal Science Educatia, 2(2), 1-20.

Tegeh, I. M., \& dkk. (2014). Model Penelitian Pengembangan. Yogyakarta: Graha Ilmu.

Tjiptiany, E. N., \& Muksar, M. (2016). Pengembangan Modul Pembelajaran Untuk Membantu Siswa Sma Kelas X Dalam Memahami Materi Peluang. Jurnal Pendidikan.

Tri Hastuti, E., Sunarno, W., \& Sukarmin. (2014). Pengembangan Modul IPA Terpadu Berbasis Penemuan Dengan Tema SPAGHETTI. In Prosiding SNFPF (Vol. 5, pp. 173-185).

Utami, T. N., Jatmiko, A., \& Suherman. (2018). Pengembangan Modul Matematika dengan Pendekatan Science, Technology, Engineering, And Mathematics (STEM) pada Materi Segiempat. Desimal: Jurnal Matematika, 1(2), 165-172.

Wati, W. (2015). Pengembangan Modul Pembelajaran Fisika SMA Terintegrasi Penanggulangan Bencana Tanah Longsor. Al-Biruni: Jurnal Ilmiah Pendidikan Fisika, 4(1), 109-119.

Wibowo, E., \& Pratiwi, D. D. (2018). Pengembangan Bahan Ajar Menggunakan Aplikasi Kvisoft Flipbook Maker Materi Himpunan. Desimal: Jurnal Matematika, 1(2), 147-156.

Widiana, I. W., Jampel, N., \& Jampel, I. N. (2016). Learning Model and Form of Assesment toward The Inferensial Statistical Achievement by Controlling Numeric Thingking Skills Achievement Form of assessment Inferential statistical Learning model Numeric thinking skills. International Journal of Evaluation and Research in Education (IJERE).

Wijayanti, S., \& Sungkono, J. (2017). 
Desimal, 2 (3), 2019 - 258

Dewi Ariskasari, Dona Dinda Pratiwi

Pengembangan Perangkat

Pembelajaran mengacu Model

Creative Problem Solving berbasis

Somatic, Auditory, Visualization, Intellectually. Al-Jabar: Jurnal Pendidikan Matematika, 8(2), 101110.

Winkel. (2009). Psikologi Pengajaran. Yogyakarta: Media Abadi.

Yuliana, R. (2017). Pengembangan Perangkat Pembelajaran Dengan Pendekatan PMRI Pada Materi
Bangun Ruang Sisi Lengkung untuk SMP Kelas IX. Jurnal Pendidikan Matematika, 6(1), 60-67.

Yuliati, L., Riantoni, C., \& Mufti, N. (2018). Problem Solving Skills on Direct Current Electricity through InquiryBased Learning with PhET Simulations. International Journal of Instruction, 11(4), 123-138. https://doi.org/10.12973/iji.2018.1 149a 